\title{
Eines schönen Tages, da
}

\section{Eingeliefert}

Leben plattgewalzt

wehrlos, festgeschnallt

auf dem Operationstisch.

Das Skalpell in der Hand des Schicksals gnadenlos präzise der Schnitt ins Innere.

Betäubt die Träume, seziert

bis auf die Knochen abgeschabt.

Die Nerven blankgelegt, zersägt.

Lebensziele vollnarkotisiert

in Dumpfheit erstickt

Mit Aderklemmen abgewürgt.

Das Glück in rosa Scherben

Pinzette um Pinzette

aus den Wunden gezogen

auf den Abwurftisch gelegt

durch Verzweiflung ersetzt.

Lebenslust wie Muskelstränge lahmgelegt

ihre Befehlsverweigerung zur Norm erklärt.

Mutlosigkeit eine Tugend

Entbehrung als Auszeichnung.

\section{Jacqueline Crevoisier}

Die Texte von Jacqueline Crevoisier
stammen aus ihrem Gedichtband

«Eines schönen Tages, da»,

erschienen im Verlag Edition Isele, Eggingen (ISBN 978-3-86142-554-0).

Crevoisier wurde in diesem Jahr

der Zürcher Lyrik-Preis verliehen.

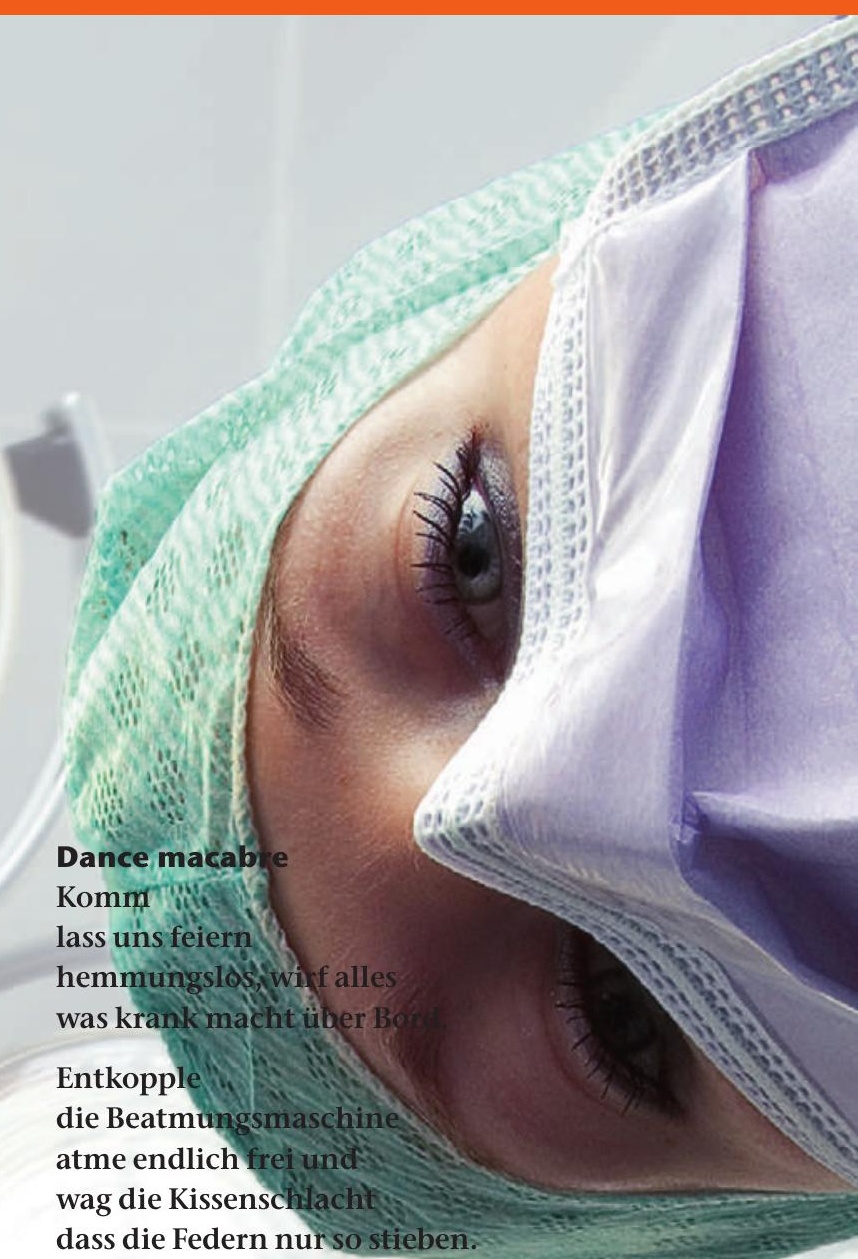

dass die Federn nur so stieben.

Wirf

die Bettpfanne mit aller Kraft

durchs geschlossene Fenster

und ergötz dich an

der erhöhten Herzfrequenz.

Streu

in den Instrumentenkorb

die buntesten Blumen und

schalte die Operationstischlampen

auf Schummerlicht.

Schwing dich

an den schwenkbaren Monitorarm

schaukle an ihm wie ein Affe am Kronleuchter.

Schmeiss mit Bananenschalen und lass die

Gesundheitsfanatiker auf ihnen ausrutschen.

\section{Setz dich}

ans Röntgenschaltpult

retouchier deine Knochen heil und

programmier den Herzschrittmacher

auf Walzer, Tango und auf Glück.

\section{Komm -}

wag es zu feiern

lass die Korken knallen

füll fröhlichen Champagner

in die traurige Infusionsflasche und steig beseligt aus

deiner vorprogrammierten Urne.

Jacqueline Crevoisier 